\title{
Preparation of Chitin, Study of Physicochemical Properties and Biopesticide Activities
}

\author{
Yuli Rohyami ${ }^{\mathrm{a}}$, Reni Banowati Istiningrum \\ Program Studi DIII Analis Kimia FMIPA UII \\ Jl. Kaliurang Km 14,5 Yogyakarta, ${ }^{a}$ Email : rohyami@uii.ac.id
}

\begin{abstract}
Chitin was preparated from shrimp shells by chemically method. Preparation was carried out by deproteination shrimp shells powder $\leq 150$ mesh with $1-2 \mathrm{M} \mathrm{NaOH}$, demineralization followed by reaction with $1.0 \mathrm{M} \mathrm{HCl}$ and depigmentation with $(1: 2: 4, \mathrm{v} / \mathrm{v})$ of chloroform : methanol : water. Physicochemical properties of chitin was determined from characterization of infrared spectra, ash value, loss on drying and total of nitrogen. Biopesticide activities of chitin was done to pest Bemisia tabaci at guava leaves with various concentration from 0.5 to $2.0 \%$ chitin on $3 \% \mathrm{v} / \mathrm{v}$ acetic acid.

This study indicated that concentration of $\mathrm{NaOH}$ on deproteination process effected to its physicochemicals properties. Effectivity of $2 \mathrm{M} \mathrm{NaOH}$ on deproteination reaction was higher than 1 $\mathrm{M} \mathrm{NaOH}$. The degree of chitin deacetylation from $2 \mathrm{M} \mathrm{NaOH}$ was $13.61 \%$ and had lower molar ratio of total nitrogen. The degree of deacetylation of chitin from $1 \mathrm{M} \mathrm{NaOH}$ had lower and had higher molar ratio of total nitrogen. Physicochemicals properties of chitin quite an impact on its ability to reduce pest Bemisia tabaci. Biopesticide activity assay showed that treatment for 2 days on average mortality rate of $13.83 \%$. Deacetylation of chitin which has a higher degree have a greater ability biopesticide with a mortality rate of up to $38.24 \%$. This study the effect of deproteination process to biopesticide activities of chitin.
\end{abstract}

Key Words : chitin, degree of deacetilation, molar ratio, biopesticide, Bemisia tabaci

\begin{abstract}
ABSTRAK
Preparasi kitin telah dilakukan dari cangkang udang dengan menggunakan metode kimiawi. Preparasi dilakukan dengan proses deproteinasi serbuk cangkang udang $\leq 150$ mesh dengan $\mathrm{NaOH} 1-$ $2 \mathrm{M}$ dilanjutkan dengan reaksi demineralisasi dengan $\mathrm{HCl}$ 1,0 $\mathrm{M}$ dan depigmentasi dengan kloroform, metanol dan air $(1: 2: 4, \mathrm{v} / \mathrm{v})$. Sifat fisikokimiawi kitin ditentukan berdasarkan spektra inframerah serta berdasarkan hasil penentuan kadar abu, kadar air, dan total nitrogen. Uji aktivitas biopestisida kitin dilakukan terhadap hama kutu putih (Bemisia tabaci) pada daun jambu biji merah dengan variasi konsentrasi $0,5-2,0 \%$ kitin dalam asam asetat $3 \% \mathrm{v} / \mathrm{v}$.

Hasil penelitian menunjukkan bahwa konsentrasi larutan $\mathrm{NaOH}$ yang digunakan pada reaksi deproteinasi memberikan pengaruh terhadap sifat fisikokimiawi. Efektivitas larutan $\mathrm{NaOH} 2 \mathrm{M}$ dalam reaksi deproteinasi kitin lebih besar daripada larutan $\mathrm{NaOH} 1 \mathrm{M}$. Kitin yang dideproteinasi dengan larutan $\mathrm{NaOH} 2 \mathrm{M}$ mempunyai derajat deasetilasi 13,61 \% dan memiliki rasio molar total nitrogen yang lebih rendah. Derajat deasetilasi kitin yang dideproteinasi dengan larutan $\mathrm{NaOH} 1 \mathrm{M}$ lebih rendah dan memiliki rasio molar total nitrogen yang lebih tinggi. Sifat fisikokimiawi kitin cukup memberikan pengaruh terhadap kemampuan kitin dalam mengurangi hama Bemisia tabaci. Uji aktivitas biopestisida menunjukkan bahwa selama perlakuan 2 hari tingkat mortalitas rata-rata 13,83\%. Kitin yang mempunyai derajat deasetilasi yang lebih tinggi memiliki kemampuan biopestisida lebih besar dengan tingkat mortalitas hingga 38,24\%. Hasil penelitian ini menunjukkan adanya pengaruh efektivitas deproteinasi terhadap aktivitas kitin sebagai biopestisida.
\end{abstract}

Kata-kata kunci : kitin, derajat deasetilasi, rasio molar, biopestisida, Bemisia tabaci 


\section{Pendahuluan}

Kitin merupakan senyawa polisakarida linear yang mengandung $\mathrm{N}$-asetil-D-glukosamin yang terikat $\beta \quad$ Kitin termasuk golongan polisakarida yang mengandung nitrogen, berwarna putih, keras, dan tidak elastis. Kitin mempunyai derajat deasetilasi $5-15 \%$, sedangkan kitosan berkisar $70-95 \%$. Semakin tinggi derajat deasetilasinya, menyebabkan kelarutannya semakin rendah. Menurut Cheba (2011), kitin mempunyai massa molekul 1,03.10 $-2,5 \cdot 10^{6}$ Da. Kitin bersifat hidrofobik dan tidak larut dalam air tetapi larut dalam beberapa pelarut organik pada $\mathrm{pH}$ rendah. Adanya gugus hidroksil dan asam amino memungkinkan kitin mudah disubstitusi dengan gugus lain.

Kitin bersifat biodegradable, biocompatible, citocompatible, dan mempunyai bioaktivitas serta daya adsorpsi yang ditentukan oleh sifat biologi dan fisikokimiawinya (Kumirska, et al., 2011). Sifat biologi dan fisikokimiawi kitin dipengaruhi oleh derajat deasetilasinya.

Kitin dapat diekstrak dari binatang crustacea, insekta, moluska dan fungi melalui ektraksi secara kimiawi atau biologi. Ektraksi kitin secara kimiawi melibatkan reaksi deproteinasi dengan larutan alkali, seperti larutan $\mathrm{NaOH}$. Efektifitas reaksi deproteinasi dipengaruhi oleh konsentrasi larutan $\mathrm{NaOH}$ yang digunakan tanpa memberikan perbedaan hasil karakterisasi pada spektra kitin yang dihasilkan (Junaidi, et al., 2009). Efektivitas $\mathrm{NaOH}$ dalam reaksi deproteinasi diduga akan kualitas kitin yang dihasilkan. Adanya protein sisa yang berikatan dengan kitin akan menyebabkan perbedaan sifat fisikokimiawinya.

Sifat fisikokimiawi kitin yang telah melewati proses kimiawi akan berpengaruh pada bioaktivitasnya. Salah satu aplikasi kitin dan kitosan adalah sebagai kemampunannya sebagai senyawa yang memiliki aktivitas biopestisida (Arbia, et al., 2013, Yanti, et al., 2009).

Penelitian ini dilakukan untuk mempelajari kemampuan kitin sebagai senyawa biopestisida pada hama pertanian, seperti kutu putih (Bemisia tabaci) pada tanaman buah. Uji bioaktivitas kitin dapat dilakukan dengan mempelajari pengaruh konsentrasi kitin terhadap tingkat mortalitasnya (Khan dan Qamar, 2011; Sujak dan Diana, 2012). Hasil penelitian ini diharapkan dapat mereduksi penggunaan pestisida, terutama pada produk buah dan sayur yang dikonsumsi dalam keadaan segar.

\section{Tujuan Penelitian}

Tujuan penelitian ini adalah sebagai berikut:

1. Mempelajari pengaruh konsentrasi larutan $\mathrm{NaOH}$ dalam reaksi deproteinasi terhadap sifat fisikokimiawi kitin 
2. Mempelajari pengaruh sifat fisikokimiawi dan konsentrasi kitin terhadap hasil uji aktivitas sebagai biopestisida hama kutu putih (Bemisia tabaci)

\section{Metode Penelitian}

Peralatan yang digunakan dalam penelitian ini adalah spektrofotometer inframerah Shimadzu FTIR 8201PC, neraca analitik, oven, seperangkat alat soxhlet, pengaduk magnetik, ayakan 150 mesh, dan peralatan gelas laboratorium.

Bahan utama dalam penelitian ini adalah cangkang udang putih yang diperoleh dari supplier udang yang ada di Yogyakarta. Bahan yang digunakan dalam penelitian ini adalah natrium hidroksida $(\mathrm{NaOH})$, metanol $\left(\mathrm{CH}_{3} \mathrm{OH}\right)$, kloroform $\left(\mathrm{CHCl}_{3}\right)$, asam asetat $\left(\mathrm{CH}_{3} \mathrm{COOH}\right)$ asam klorida $(\mathrm{HCl})$, asam sulfat $\left(\mathrm{H}_{2} \mathrm{SO}_{4}\right)$. Semua bahan yang diproduksi oleh Merck. Bahan lain yang digunakan adalah indikator fenil ftalein, indikator metil merah, indikator metil biru, akuades, kertas saring Wathman 42, dan kertas $\mathrm{pH}$ universal.

Ekstraksi kitin dilakukan dengan deproteinasi, demineralisasi dan depigmentasi mengacu pada penelitian Arbia, et al. (2013). Sebanyak 50 g serbuk cangkang ukuran $\leq 100$ mesh direfluks dengan $500 \mathrm{~mL}$ larutan $\mathrm{NaOH} 1$ - $2 \mathrm{M}$ pada temperatur $65^{\circ} \mathrm{C}$ selama $2 \mathrm{jam}$. Hasil deproteinasi didemineralisasi dengan $250 \mathrm{~mL}$ $\mathrm{HCl} 1 \mathrm{M}$ selama 60 menit pada temperatur kamar. Kitin yang telah diperoleh didepigmentasi dengan menggunakan $50 \mathrm{~mL}$ campuran kloroform, metanol dan air $(1: 2: 4$, $\mathrm{v} / \mathrm{v})$.

\section{Penentuan sifat Fisikokimiawi}

Derajat deasetilasi kitin ditentukan dengan spektrofotometri inframerah menggunakan metode baseline Baxter dengan membandingkan absorbansi pada $1655 \mathrm{~cm}^{-1}$ dan $3450 \mathrm{~cm}^{-1}$ seperti yang dirujuk oleh Brugnerotto, et al. (2001) dan Junaidi, et al., (2009) dalam persamaan 1.

$$
\mathrm{DD}=100-\left[\frac{\mathrm{A}_{1655}}{\mathrm{~A}_{3450}} \times 115\right] \ldots \text { Persamaan } 1 .
$$

(Sumber : Junaidi, et al., 2009)

Kadar nitrogen total ditentukan dengan metode kjedahl seperti yang dilakukan dalam penelitian (Chandumpai, et al., 2004; Mizani dan Aminlari, 2007). Total nitrogen dalam kitin ditentukan dengan Persamaan 2.

$$
\text { Total } \mathrm{N}=\frac{\left(\mathrm{V}_{1}-\mathrm{V}_{2}\right) \mathrm{N} \times 14,007 \times \mathrm{f}}{\mathrm{w} .1000} \times 100 \% \text {...Persamaan } 2 .
$$

(Sumber : Chandumpai, et al., 2004; Mizani dan Aminlari, 2007)

Kadar air ditentukan secara gravimetri dengan pemanasan pada temperatur $105^{\circ} \mathrm{C}$ selama 3 jam. Kadar abu ditentukan secara gravimetri dengan pengabuan pada temperatur $650^{\circ} \mathrm{C}$ selama 4 jam (Puvada, et al., 2012).

\section{Uji Aktivitas Biopestisida}

Uji bioaktivitas kitin dapat dilakukan dengan mempelajari pengaruh konsentrasi 
senyawa biopestisida terhadap tingkat mortalitasnya (Khan dan Qamar, 2011; Sujak dan Diana, 2012). Uji aktivitas biopestisida kitin dilakukan pada hama kutu putih kutu putih (Bemisia tabaci) pada tanaman jambu biji merah. Uji biopestisida dilakukan pada variasi konsentrasi $0,5-2 \%$ kitin dalam asama asetat 3 $\%$ v/v. Daun yang terkena hama kutu putih dimasukkan ke dalam botol dan diberi dengan larutan kitin. Bioaktivitas kitin diamati dari tingkat mortalitas kutu putih (Bemisia tabaci).

\section{Pembahasan}

\section{Penentuan sifat Fisikokimiawi}

Karakterisasi kitin dengan data spektrofotometer inframerah (IR) dapat ditunjukkan pada Gambar 1 dan Gambar 2.

Konsentrasi larutan $\mathrm{NaOH}$ tidak memberikan perbedaan yang berarti terhadap spektra inframerah (IR) seperti yang diberikan pada Gambar 1 dan Gambar 2. Konsentrasi larutan $\mathrm{NaOH}$ dalam reaksi deproteinasi tidak memberikan perbedaan pita serapan kitin dan kitosan (Junaidi, et al., 2009).

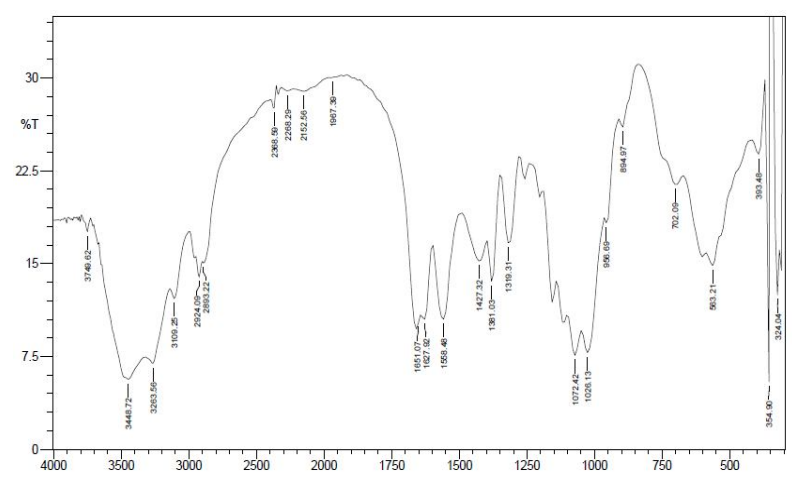

Gambar 1. Spektra IR kitin (1M)

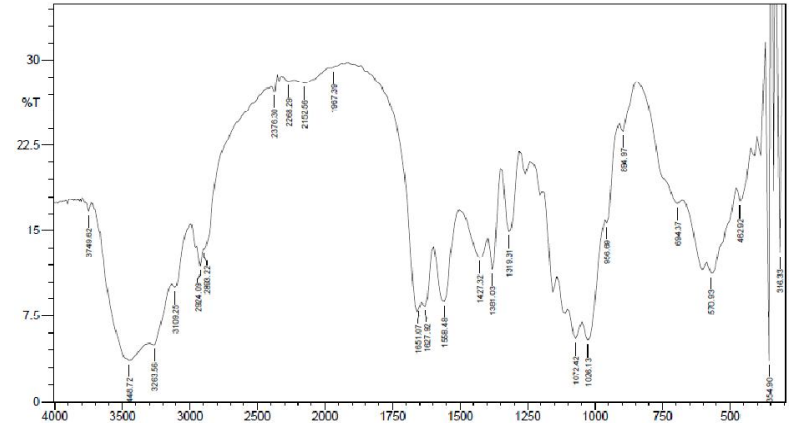

Gambar 2. Spektra IR kitin (2M)

Spektra IR kitin menunjukkan adanya vibrasi ulur gugus - $\mathrm{OH}$ alifatik yang terikat pada setiap unit monomer kitin pada bilangan gelombang 3348,72 $\mathrm{cm}^{-1}$, vibrasi ulur - $\mathrm{NH}$ dari gugus asetamida pada $1558,43 \mathrm{~cm}^{-1}$, vibrasi ulur $-\mathrm{C}=\mathrm{O}$ dari gugus asetamida pada $1651,07 \mathrm{~cm}^{-1}$, vibrasi ulur - $\mathrm{C}-\mathrm{N}$ - dari gugus asetamida pada $1319,31 \mathrm{~cm}^{-1}$, vibrasi ulur $-\mathrm{C}-\mathrm{H}-$ dari $-\mathrm{CH}_{3}$ pada $1381,03 \mathrm{~cm}^{-1}$ dan vibrasi -C-O-C- dari glukosamin pada 1072,43 dan $1026,13 \mathrm{~cm}^{-1}$.

Konsentrasi larutan $\mathrm{NaOH}$ mempengaruhi besarnya derajat deasetilasi kitin. Derajat deasetilasi kitin ditentukan dengan spektrofotometri inframerah (IR) menggunakan metode baseline Baxter dengan membandingkan absorbansi pada $1651,07 \mathrm{~cm}^{-1}$ dan $3348,72 \mathrm{~cm}^{-1}$ (Brugnerotto, 2001 dan Junaidi, et al., 2009). Adanya perbedaan derajat deasetilasi kitin ini juga ditunjukkan dari perbedaan intensitas serapan untuk vibrasi ulur $-\mathrm{C}=\mathrm{O}$ dari gugus asetamida pada $1651,07 \mathrm{~cm}^{-1}$.

Derajat deasetilasi hasil deproteinasi dengan larutan $\mathrm{NaOH} 2 \mathrm{M}$ adalah 13,61 \% lebih tinggi dari hasil deproteinasi dengan larutan 
$\mathrm{NaOH} 1 \mathrm{M}$ sebesar 8,80\%. Perbedaan derajat deasetilasi kitin masih berada pada kisaran 5 - 15 $\%$ (Cheba, 2011).

Hasil pengujian kadar abu, air, dan kadar nitrogen menunjukkan adanya rasio molar $\mathrm{C}: \mathrm{H}$ : $\mathrm{O}: \mathrm{N}$ hasil deproteinasi kitin dengan $\mathrm{NaOH} 1 \mathrm{M}$ dan $2 \mathrm{M}$ adalah 17:39:20:4 dan 16:45:22:1.

Tabel 1. Derajat Deasetilasi (DD) dan Rasio C:H:O:N

\begin{tabular}{|c|c|c|c|c|c|}
\hline Kitin $(\mathrm{NaOH})$ & \multirow{2}{*}{\begin{tabular}{c} 
DD \\
\cline { 3 - 6 }
\end{tabular}} & \multicolumn{5}{|c|}{ Rasio molar } \\
\cline { 3 - 6 } & $\mathrm{C}$ & $\mathrm{H}$ & $\mathrm{O}$ & $\mathrm{N}$ \\
\hline Kitin (1M) & 8,80 & 17 & 39 & 20 & 4 \\
Kitin (2M) & 13,61 & 16 & 45 & 22 & 1 \\
\hline
\end{tabular}

Larutan $\mathrm{NaOH} 2 \mathrm{M}$ mampu melepaskan

protein yang terikat pada cangkang udang lebih besar daripada kemampuan larutan $\mathrm{NaOH} 1 \mathrm{M}$. Efektivitas larutan $\mathrm{NaOH}$ pada reaksi deproteinasi kitin dapat ditunjukkan dari besarnya kadar nitrogen. Rasio nitrogen yang terkandung dalam kitin hasil deproteinasi dengan $\mathrm{NaOH} 1 \mathrm{M}$ lebih besar apabila dibandingkan dengan hasil deproteinasi kitin dengan $\mathrm{NaOH} 2$ M.

\section{Uji Aktivitas Biopestisida}

Hasil uji aktivitas biopestisida kitin terhadap mortalitas hama kutu putih (Bemisia tabaci) pada daun jambu biji merah menunjukkan adanya pengaruh efektifitas deproteinasi kitin terhadap bioaktivitasnya, seperti yang ditunjukkan pada Tabel 2.

Pengaruh efektifitas hasil deproteinasi terhadap aktivitas biopestisida yang diberikan pada Gambar 2 menunjukkan bahwa kitin dapat mempengaruhi tingkat mortalitas hama kutu putih (Bemisia tabaci). Mortalitas hama kutu putih (Bemisia tabaci) dipengaruhi oleh konsentrasi kitin dan sifat fisikokimiawi kitin. Kitin hasil reaksi deproteinasi dengan larutan $\mathrm{NaOH} 2 \mathrm{M}$ dan memiliki derajat deasetilasi lebih tinggi dapat meningkatkan tingkat mortalitas hama kutu putih (Bemisia tabaci) hingga 4,51\% lebih tinggi dibandingkan dengan hasil deproteinasi dengan larutan $\mathrm{NaOH} 2 \mathrm{M}$, yaitu 3,5 $\%$ dalam perlakuan selama 2 hari.

Hasil uji aktivitas pestisida terhadap hama kutu putih ini juga menunjukkan adanya pengaruh konsentrasi kitin terhadap tingkat mortalitas hama. Konsentrasi biopestisida akan menaikkan tingkat mortalitas hama, sehingga semakin tinggi konsentrasi senyawa aktif biopestisida akan semakin meningkatkan bioaktivitasnya (Khan dan Qamar, 2011; Sujak dan Diana, 2012).

Tabel 2. Uji Aktivitas Biopestisida Kitin terhadap Mortalitas Kutu Putih (Bemisia tabaci)

\begin{tabular}{|c|c|c|}
\hline \multirow{2}{*}{$\begin{array}{c}\text { Konsentrasi } \\
(\%)\end{array}$} & \multicolumn{2}{|c|}{ Mortalitas (\%) } \\
\cline { 2 - 3 } & Hari I & Hari II \\
\hline 0 & 5,00 & 11,67 \\
\hline Kitin(1M) & & \\
0,5 & 10,17 & 13,56 \\
1,0 & 8,33 & 11,11 \\
1,5 & 16,28 & 20,93 \\
2,0 & 8,51 & 11,70 \\
\hline Kitin(2M) & & \\
0,5 & 6,59 & 13,19 \\
1,0 & 10,34 & 17,24 \\
1,5 & 13,89 & 33,33 \\
2,0 & 26,47 & 38,24 \\
\hline
\end{tabular}




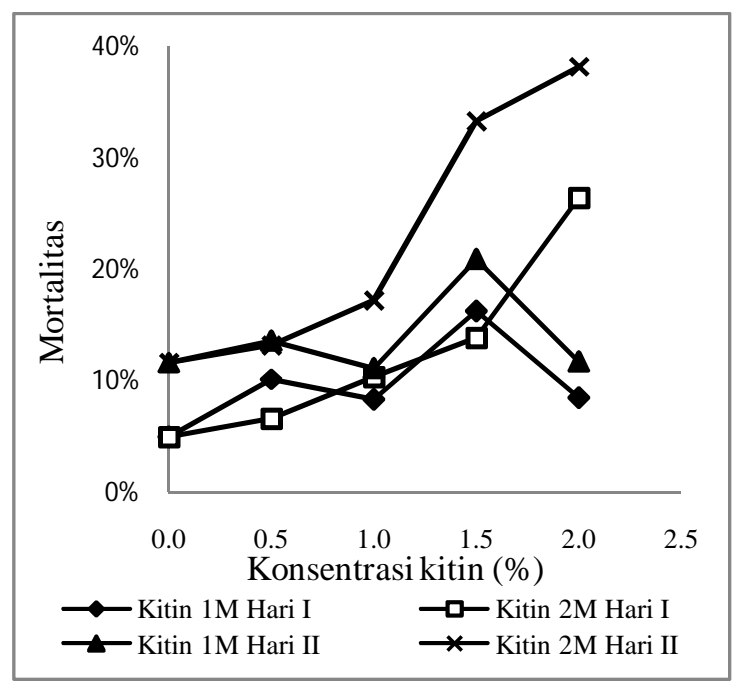

Gambar 3. Pengaruh Kitin terhadap Mortalitas Hama Kutu Putih

Kemampuan kitin dalam mengurangi hama kutu putih selama perlakuan 2 hari rata-rata mencapai tingkat mortalitas sebesar 13,83\%. Kitin yang memiliki derajat deasetilasi lebih tinggi mempunyai bioaktivitas yang lebih besar dengan tingkat mortalitas mencapai hingga $38,24 \%$.

Hasil penelitian ini menunjukkan adanya pengaruh efektivitas deproteinasi terhadap aktivitas kitin sebagai biopestisida. Reaksi deproteinasi kitin akan meningkatkan jumlah sisi aktif gugus asetamida dan gugus hidroksil yang terikat pada cincin glukosamin. Gugus tersebut yang dapat memberikan respon biologis dalam menghambat pertumbuhan sel (Yanti, et al., 2009). Kitin mempunyai kemampuan sebagai inhibitor (Khan dan Qamar, 2011) sehingga apabila sisi aktif pada gugus tersebut tidak berikatan dengan protein dalam cangkang udang maka bioaktivitasnya akan semakin meningkat.

\section{Kesimpulan}

Berdasarkan hasil penelitian dapat disimpulkan bahwa :

1. Konsentrasi larutan $\mathrm{NaOH} 2 \mathrm{M}$ yang digunakan dalam preparasi kitin mampu meningkatkan efektivitas reaksi deproteinasi kitin dibandingkan dengan larutan $\mathrm{NaOH} 1$ M, sehingga berpengaruh pada besarnya derajat deasetilasi kitin dan besarnya rasio molar total nitrogen.

2. Efektivitas reaksi deproteinasi mempengaruhi besarnya aktivitas biopestisida pada hama kutu putih (Bemisia tabaci) sehingga akan meningkatkan tingkat mortalitas hama.

\section{Ucapan Terimakasih}

Ucapan terimakasih yang sebesarbesarnya kami ucapkan kepada Saudara Ida, Erna, dan Aim atas bantuannya dalam penelitian ini.

\section{Pustaka}

Arbia, W., Arbia, L. Lydia Adour, L., Amrane, A., 2013, Chitin extraction from crustacean shells using biological methods - a review. Food Technol. Biotechnol, 51, 12-25

Brugnerotto, J., Lizardi, J., Goycoolea, F.M., Monal, W.A.E., Ares J.D., 2001, An infrared investigation in relation with chitin and chitosan characterization, Polymer, 42, 3569-3580

Chandumpai, A. Singhpibulporn, N., Faroongsarng, D., Sornprasit, P., 2004, Prepration and physico-chemicals 
characteriztion of chitin and chitosan from the pens of squid species, loligo lessosiana and loligo formosana. Carbohydrate Polimer, 58, 467-474

Cheba, B.A., 2011, Chitin and chitosan : marine biopolymers with unique properties and versatile application, Global Journal of Biotechnology \& Biochemistry, 6, 149-153

Junaidi, A.B., Kartini, I., Rusdiarso, B. (2009) Chitosan preparation with multistage deacetylation of chitin and ivestigation of its physicochemical properties, Indo. J. Chem., 9, 369-372

Khan, I., Qamar, A., 2011, Biological cctivity of andalin (flucycloxuron), a novel chitin synthesis inhibitor, on red cotton stainer dysdercus koenigii (fabricius), Research Article Biology and Medicine, 3, 324-335

Kumirska, J., Weinhold, M.X., Thoming, J., Stepnowski, P., 2011, Biomedical activity of chitin/chitosan based materials influence of physicochemical properties apart from molecular weight and degree of $\mathrm{N}$ acetylation, Polymers, 3, 1875-1901

Mizani, A.M., Aminlari, B.M., 2007, A new process for deproteinzation of chitin from shrimp head waste, Proceedings of European Congress of Chemical Engineering(ECCE-6), Diselenggarakan di Copenhagen

Puvvada,Y.S., Vankayalapati, S., Sukhavasi, S., 2012, Extraction of chitin from chitosan from exoskeleton of shrimp for application in the pharmaceutical industry, International Current Pharmaceutical Journal, 1, 258-263

Sujak, Diana, N.E. (2012) Uji Efektivitas Ekstrak Nikotin Formula 1 (Pelarut Ether) terhadap Mortalitas Aphis gossypie (Homoptera aphididae ) Agrovigor 5(1) : 47 - 51, 2012

Yanti, S.D., Nugroho, P.T., Aprisa, R. Mulyana, E., 2009, The potential of chitosan as alternative biopesticide for postharvest plants, Asian Journal of Food and AgroIndustry, Special Issue, 241-248 